\title{
GLOSY
}

PRZEGLLD SEJMOWY

nr 3(158)/2020, s. 237-254; https://doi.org/10.31268/PS.2020.42

\section{Glosa do uchwały składu połączonych Izb: Cywilnej, Karnej oraz Pracy i Ubezpieczeń Społecznych Sądu Najwyższego z 23 stycznia 2020 r., sygn. akt BSA I-4110-1/20*}

Sąd Najwyższy uchwałą z 23 stycznia 2020 r. niepełnych trzech Izb: Cywilnej, Karnej oraz Pracy i Ubezpieczeń Społecznych podjął próbę skategoryzowania sędziów na tych, którzy mają prawo orzekania, tych, którzy takiego prawa nie mają, a także tych, których orzeczenia zapadłe do momentu podjęcia przedmiotowej uchwały są wadliwe. Sąd podjął tę uchwałę w kontrowersyjnych okolicznościach, mianowicie w warunkach zawieszonego dzień wcześniej postępowania oraz bez podstawy prawnej w prawie materialnym, ingerując tym samym w kompetencje władzy ustawodawczej i w prerogatywę Prezydenta RP. W tej sytuacji przedmiotowa uchwała nie jest orzeczeniem SN i nie wywołuje skutków prawnych.

SŁowa Kluczowe: Sąd Najwyższy, podział władzy, skutki prawne, Pierwszy Prezes Sądu Najwyższego, nienależyta obsada sądu, sprzeczność składu sądu z przepisami prawa

\section{Commentary to the resolution of the joint Chambers: Civil, Criminal and Labour Law and Social Security, of the Supreme Court of 23 January 2020, ref. no. BSA I-4110-1/20}

In the resolution of 23 January 2020 issued by incomplete three Chambers: Civil Chamber, Criminal Chamber and Labour Law and Social Security Chamber, the Supreme Court made an attempt at categorising judges into those authorised to pass judgments and those unauthorised, as well as judges whose judgments passed prior to issuing the resolution are considered defective. The Court issued the resolution in controversial circumstances, that is in the conditions of proceedings suspended only a day earlier and with no legal basis in the material law, thus interfering in the competences of the executive power and the prerogative of the President of the Republic of Poland. Therefore, the resolution is not a judgment of a Supreme Court and bears no legal effects.

Key words: Supreme Court, separation of powers, legal effects, the First President of the Supreme Court, inadequate court staff, court staff in contradiction to the provisions of law

\footnotetext{
* Uchwała składu połączonych Izb: Cywilnej, Karnej oraz Pracy i Ubezpieczeń Społecznych SN z 23 stycznia 2020 r., <http://www.sn.pl/aktualnosci/SitePages/Wydarzenia>, dostęp 5 II 2020.
} 


\section{Tezy uchwały}

Na wniosek Pierwszego Prezesa Sądu Najwyższego z 15 stycznia 2020 r. o rozstrzygnięcie rozbieżności w wykładni prawa występującej w orzecznictwie połączony skład Izb: Cywilnej, Karnej oraz Pracy i Ubezpieczeń Społecznych Sądu Najwyższego podjął uchwałę, w której stwierdził:

1. Nienależyta obsada sądu $w$ rozumieniu art. 439 \$ 1 pkt 2 k.p.k. ${ }^{1}$ albo sprzeczność składu sądu z przepisami prawa w rozumieniu art. 379 pkt 4 k.p.c. ${ }^{2}$ zachodzi także wtedy, gdy w składzie sądu bierze udział osoba powołana na urząd sędziego Sądu Najwyższego na wniosek Krajowej Rady Sadownictwa ukształtowanej w trybie określonym przepisami ustawy z dnia 8 grudnia 2017 r. o zmianie ustawy o Krajowej Radzie Sadownictwa oraz niektórych innych ustaw (Dz.U. z 2018 r. poz. 3).

2. Nienależyta obsada sądu w rozumieniu art. 439 \& 1 pkt 2 k.p.k. albo sprzeczność składu sądu z przepisami prawa w rozumieniu art. 379 pkt 4 k.p.c. zachodzi także wtedy, gdy w składzie sądu bierze udział osoba powołana na urząd sędziego w sadzie powszechnym albo wojskowym na wniosek Krajowej Rady Sadownictwa uksztattowanej $w$ trybie określonym przepisami ustawy z dnia 8 grudnia 2017 r. o zmianie ustawy o Krajowej Radzie Sądownictwa oraz niektórych innych ustaw (Dz.U. z 2018 r. poz. 3), jeżeli wadliwość procesu powoływania prowadzi, w konkretnych okolicznościach, do naruszenia standardu niezawisłości i bezstronności $w$ rozumieniu art. 45 ust. 1 Konstytucji Rzeczypospolitej Polskiej, art. 47 Karty Praw Podstawowych Unii Europejskiej oraz art. 6 ust. 1 Konwencji o ochronie praw człowieka i podstawowych wolności.

3. Wykładnia art. 439 \& 1 pkt 2 k.p.k. oraz art. 379 pkt 4 k.p.c. przyjęta w punktach 1 i 2 niniejszej uchwaty nie ma zastosowania do orzeczeń wydanych przez sady przed dniem jej podjęcia oraz do orzeczeń, które zostana wydane $w$ toczacych się w tym dniu postepowaniach na podstawie Kodeksu postępowania karnego przed danym składem sądu.

4. Punkt 1 niniejszej uchwaty ma zastosowanie do orzeczeń wydanych z udziałem sędziów Izby Dyscyplinarnej utworzonej w Sadzie Najwyższym na podstawie ustawy z dnia 8 grudnia 2017 r. o Sądzie Najwyższym (Dz.U. z 2018 r. poz. 5, ze zm.) bez względu na datę wydawanych orzeczeń.

Sąd Najwyższy podjął próbę kategoryzacji sędziów na tych z sądów powszechnych i wojskowych, którzy mogą orzekać bez przeszkód, bo zostali powołani na wniosek

${ }^{1}$ Art. $439 \S 1$ pkt 2 ustawy z dnia 6 czerwca 1997 r. - Kodeks postępowania karnego (tekst jedn. Dz.U. z 2020 r. poz. 30): „Niezależnie od granic zaskarżenia i podniesionych zarzutów oraz wpływu uchybienia na treść orzeczenia sąd odwoławczy na posiedzeniu uchyla zaskarżone orzeczenie, jeżeli sąd był nienależycie obsadzony lub którykolwiek z jego członków nie był obecny na całej rozprawie".

2 Art. 379 pkt 4 ustawy z dnia 17 listopada 1964 r. - Kodeks postępowania cywilnego (tekst jedn. Dz.U. z 2019 r. poz. 1460, 1469, 1495, 1649, 1655, 1798, 1802, 1818, 2070, 2089, 2128, 2217): „Nieważność postępowania zachodzi, jeżeli skład sądu orzekającego był sprzeczny z przepisami prawa albo jeżeli w rozpoznaniu sprawy brał udział sędzia wyłączony z mocy ustawy”. 
poprzedniej Krajowej Rady Sądownictwa [dalej: KRS], ukształtowanej przed wejściem w życie ustawy z 8 grudnia 2017 r. o KRS, a następnie na tych, którzy mogą orzekać, mimo że o ich powołanie wnioskowała obecna KRS, ale orzeczenia składów sądowych z ich udziałem nie będą wadliwe tylko wówczas, gdy „,wadliwość procesu (ich) powoływania” nie prowadzi, „w konkretnych okolicznościach”, do „naruszenia standardu niezawisłości i bezstronności w rozumieniu art. 45 ust. 1 Konstytucji Rzeczypospolitej Polskiej, art. 47 Karty Praw Podstawowych Unii Europejskiej”. Jest także trzecia kategoria sędziów - sędziowie Sądu Najwyższego powołani przez Prezydenta RP na wniosek obecnej KRS. Ci nie mogą orzekać w ogóle, ponieważ ich obecność w składach orzekających zdaniem SN zawsze będzie prowadzić do wadliwości orzeczeń. W końcu jest jeszcze czwarta grupa sędziów - sędziowie Izby Dyscyplinarnej SN, którzy nie tylko nie mogą orzekać, zdaniem SN wyrażonym w glosowanej uchwale, ale też dotychczasowe orzeczenia wydane przez składy orzekające $\mathrm{z}$ ich udziałem są dotknięte wadą nienależytej obsady sądu lub sprzeczności składu sądu z przepisami prawa. Uchwała została wydana w zagmatwanej rzeczywistości faktycznej i prawnej, stąd konieczność jej wyjaśnienia i dokonania interpretacji uchwały w tym właśnie kontekście.

\section{Stan faktyczny i prawny}

1. W odpowiedzi na pytanie prejudycjalne składu orzekającego Izby Pracy i Ubezpieczeń Społecznych SN w sprawie zawisłej przed składem orzekającym tej Izby z odwołania sędziego Naczelnego Sądu Administracyjnego od uchwały KRS dotyczącej przejścia w stan spoczynku tego sędziego ${ }^{3}$ Trybunał Sprawiedliwości Unii Europejskiej [dalej: TSUE] 19 listopada 2019 r. wydał orzeczenie ${ }^{4}$, które stało się przedmiotem wielu analiz i komentarzy. W orzeczeniu tym TSUE stwierdził w szczególności, co następuje.

Po pierwsze, jednoznacznie wskazał, że udziela odpowiedzi na pytanie sądu odsyłającego, którym jest Izba Pracy i Ubezpieczeń Społecznych SN, w konkretnym zawieszonym postępowaniu i w sytuacji, gdy odpowiedź na to pytanie i wykładnia przepisów prawa unijnego jest niezbędna do wydania orzeczenia w tym postępowaniu. TSUE stwierdził bowiem, że „Izba Pracy i Ubezpieczeń Społecznych Sądu Najwyższego, przed którą toczą się postępowania w tych sprawach, wskazuje w postanowieniach odsyłających w sprawach C-624/18 i C-625/18, że sprawy te wpłynęły do niej, ponieważ Izba Dyscyplinarna nie została jeszcze ukonstytuowana. W tych okolicznościach sąd odsyłający docieka, czy art. 9 ust. 1 dyrektywy 2000/78 i art. 47 Karty praw podstawowych nakładają na niego obowiązek odmowy zastosowania przepisów krajowych, które zastrzegają właściwość w tych sprawach dla izby, która nie została jeszcze ukonstytuowana. Sąd ten zaznacza jednak, że pytanie to może się zdezaktualizować w razie

3 Sygn. akt III PO 7/18; C-624/18, C-625/18.

${ }^{4}$ Wyrok TSUE z 19 listopada 2019 r. w sprawach połączonych A.K. vs. Krajowa Rada Sądownictwa (C-585/18) oraz CP (C-624/18), DO (C-625/18) vs. Sąd Najwyższy, sygn. ECLI:EU:C:2019:982 <http:// curia.europa.eu/juris/document/document.jsf?>, dostęp 5 II 2020. 
faktycznego obsadzenia stanowisk sędziego w Izbie Dyscyplinarnej. Ponadto w postanowieniach odsyłających w sprawach C-585/18, C-624/18 i C-625/18 sąd odsyłający stwierdza, że zważywszy w szczególności na okoliczności, w jakich miałoby dojść do powołania nowych sędziów Izby Dyscyplinarnej, rodzą się poważne wątpliwości co do tego, czy ta izba i jej członkowie będą zapewniać wystarczające gwarancje niezawisłości i bezstronności”’

Kontynuując, TSUE dodał, że ,jedynie do sądu krajowego, przed którym zawisł spór i na którym spoczywa odpowiedzialność za wydanie orzeczenia, należy — przy uwzględnieniu okoliczności konkretnej sprawy — zarówno ocena, czy do wydania wyroku jest mu niezbędne uzyskanie orzeczenia prejudycjalnego, jak i ocena znaczenia pytań, które przedkłada Trybunałowi”. Dlatego zdaniem TSUE „odmowa wydania przez Trybunał orzeczenia w przedmiocie złożonego przez sąd krajowy wniosku jest możliwa tylko wtedy, gdy jest oczywiste, że wykładnia przepisu prawa Unii, o którą wniesiono, nie ma żadnego związku ze stanem faktycznym lub z przedmiotem postępowania głównego, gdy problem jest natury hipotetycznej [...]". TSUE ustalił jednak, że odpowiedź na pytania prejudycjalne jest konieczna, gdyż „sąd odsyłający, poprzez pytania, które skierował do Trybunału, oraz poprzez wykładnię prawa Unii, o którą w tym wypadku wnosi, zmierza do uzyskania wyjaśnień nie na temat istoty zawisłych przed nim sporów, które same w sobie dotyczą innych zagadnień z zakresu prawa Unii, lecz w odniesieniu do kwestii proceduralnej, którą sąd ten powinien rozstrzygnąc in limine litis, ponieważ dotyczy ona samej właściwości tego sądu do rozpoznania tych sporów".

Po drugie, w związku z powyższymi ustaleniami TSUE rozpoznał sprawę i ustosunkowując się do pytań prejudycjalnych, udzielił odsyłającemu sądowi krajowemu następującej odpowiedzi: „Artykuł 47 Karty praw podstawowych i art. 9 ust. 1 dyrektywy 2000/78 należy interpretować w ten sposób, że stoją one na przeszkodzie temu, by spory dotyczące stosowania prawa Unii mogły należeć do wyłącznej właściwości organu niestanowiącego niezawisłego $\mathrm{i}$ bezstronnego sądu w rozumieniu pierwszego $\mathrm{z}$ tych przepisów. Do tej ostatniej sytuacji dochodzi wówczas, gdy obiektywne okoliczności, w jakich został utworzony dany organ, oraz jego cechy, a także sposób, w jaki zostali powołani jego członkowie, mogą wzbudzić w przekonaniu jednostek uzasadnione wątpliwości co do niezależności tego organu od czynników zewnętrznych, w szczególności od bezpośrednich lub pośrednich wpływów władzy ustawodawczej i wykonawczej, oraz jego neutralności względem ścierających się przed nim interesów, i prowadzić w ten sposób do braku przejawiania przez ten organ oznak niezawisłości lub bezstronności, co mogłoby podważyć zaufanie, jakie sądownictwo powinno budzić w tych jednostkach w społeczeństwie demokratycznym”. Dlatego właśnie, stwierdził dalej TSUE, to do „sądu odsyłającego", czyli do składu orzekającego w konkretnej sprawie sędziego NSA zawisłej przed Izbą Pracy i Ubezpieczeń Społecznych SN, ,należy ustalenie, przy wzięciu pod uwagę wszystkich istotnych informacji, którymi dysponuje, czy jest tak w przypadku

\footnotetext{
${ }^{5}$ Ibidem, pkt 39 i 40.

${ }^{6}$ Ibidem, pkt 97 i 99.
} 
organu, takiego jak Izba Dyscyplinarna Sądu Najwyższego. W razie gdyby tak było, zasadę pierwszeństwa prawa Unii należy interpretować w ten sposób, że zobowiązuje ona sąd odsyłający do odstąpienia od stosowania przepisu prawa krajowego zastrzegającego dla takiego organu właściwość do rozpoznania sporów w postępowaniu głównym, ażeby spory te mogły zostać rozpatrzone przez sąd, który spełnia wyżej wskazane wymogi niezawisłości i bezstronności i który byłby właściwy w danej dziedzinie, gdyby ów przepis nie stał temu na przeszkodzie"”.

2. Po uzyskaniu powyższej odpowiedzi w sprawie z odwołania sędziego NSA od uchwały Krajowej Rady Sądownictwa z 27 lipca 2018 r. Izba Pracy i Ubezpieczeń Społecznych SN, przyjmując, że Izba Dyscyplinarna nie ma jednak gwarancji niezależności i nie spełnia wymogów niezawisłości, postanowiła nie kierować zawisłej przed nim sprawy do tej Izby i sama uchyliła uchwałę KRS w przedmiocie dalszego zajmowania stanowiska sędziego NSA, jak również oddaliła wniosek prezesa Izby Dyscyplinarnej SN z 10 października 2018 r. o przekazanie sprawy według właściwości do Izby Dyscyplinarnej ${ }^{8}$.

Izba Pracy i Ubezpieczeń Społecznych SN w ramach tego samego orzeczenia nie poprzestała jednak tylko na rozstrzygnięciu sprawy. Sformułowała zarówno w tezach ustnych wygłoszonych 5 grudnia 2019 r., jak i w komunikacie SN oraz w uzasadnieniu do wyroku następujące tezy: „wykładnia zawarta w wyroku Trybunału Sprawiedliwości UE z dnia 19 listopada 2019 r. wiąże każdy sąd w Polsce, a także każdy organ władzy państwowej”; „wyrok TSUE wyznacza jednoznaczny i precyzyjny standard oceny niezawisłości i bezstronności sądu, jaki obowiązuje we wszystkich krajach Unii Europejskiej, w tym w Polsce”; „każdy sąd w Polsce, w tym Sąd Najwyższy, ma obowiązek z urzędu badać, czy standard przewidziany w wyroku TSUE jest zapewniony w rozpoznawanej sprawie". Dlatego też, jak orzekła Izba Pracy i Ubezpieczeń Społecznych SN, „wykonując ten obowiązek, Sąd Najwyższy stwierdził, że Krajowa Rada Sądownictwa w obecnym składzie nie jest organem bezstronnym i niezawisłym od władzy ustawodawczej i wykonawczej. Sąd Najwyższy uznaje, że Izba Dyscyplinarna Sądu Najwyższego nie jest sądem w rozumieniu prawa Unii Europejskiej, a przez to nie jest sądem w rozumieniu prawa krajowego”, a „prymat prawa Unii skutkuje tym, że każdy organ państwa członkowskiego ma obowiązek zapewnić pełną skuteczność norm prawa Unii (pkt 158 wyroku TSUE), aż do pomijania niezgodnych przepisów prawa krajowego (pkt 160)"

3. Inne stanowisko zajęła Izba Kontroli Nadzwyczajnej i Spraw Publicznych SN, choć trzeba zaznaczyć, że stanowisko to dotyczy innego etapu procesu powoływania sędziów, a mianowicie odwołania od uchwał KRS w przedmiocie przedstawienia prezydentowi wniosku o powołanie do pełnienia urzędu na stanowisku sędziego.

7 Ibidem, pkt 171.

${ }^{8}$ Wyrok SN z 5 grudnia 2019 r., sygn. akt III PO 7/18, <http://www.sn.pl/aktualnosci/SitePages/ Komunikaty_o_sprawach.aspx?>, dostęp 5 II 2020.

${ }_{9}$ Ibidem. 
W uchwale siedmiu sędziów z 8 stycznia 2020 r. Izba ta orzekła, badając — w granicach podstaw odwołania - czy KRS jest organem niezależnym zgodnie z kryteriami określonymi w wyroku TSUE z 19 listopada 2019 r. w połączonych sprawach C-585/18, C-624/18 i C-625/18, że uchyla, w granicach zaskarżenia, uchwałę KRS w przedmiocie przedstawienia Prezydentowi RP kandydata do pełnienia urzędu na stanowisku sędziego, ale pod warunkiem iż ,odwołujący się wykaże, że brak niezależności Krajowej Rady Sądownictwa miał wpływ na treść tej uchwały lub jeżeli uwzględniając konstytucyjny zakaz badania skuteczności aktu ustrojowego powołania sędziego oraz wynikającego z niego stosunku ustrojowego — odwołujący się wykaże okoliczność określoną w pkt. 125, lub łącznie okoliczności wymienione w pkt. 147-151 wyroku, o którym mowa w pkt. I, wskazujące, że sąd, w składzie którego taki sędzia będzie zasiadał, nie będzie niezależny i bezstronny"10.

Powyższym orzeczeniem SN odrzucił istnienie obowiązku badania w każdej sprawie z urzędu przez wszystkie sądy w Polsce, w tym Sąd Najwyższy, standardu niezawisłości i bezstronności sądu wynikającego z art. 47 Kart praw podstawowych, rozumianego w sposób określony w wyroku TSUE z 19 listopada 2019 r. Warto podkreślić, że stanowisko to ma moc zasady prawnej.

4. Jeszcze inne stanowisko, całkowicie odmienne od tego z glosowanej uchwały połączonych izb SN, jak również skrajnie odmienne od stanowiska Izby Pracy i Ubezpieczeń Społecznych SN z 5 grudnia 2019 r., zajęła wcześniej Izba Dyscyplinarna Sądu Najwyższego. W uchwale pełnego składu Izby z 10 kwietnia 2019 r. ${ }^{11}$ stwierdzono, że „udział w składzie sądu osoby, która została powołana przez Prezydenta Rzeczypospolitej Polskiej do pełnienia urzędu na stanowisku sędziego Sądu Najwyższego w następstwie procedury zainicjowanej obwieszczeniem Prezydenta Rzeczypospolitej Polskiej wydanym bez kontrasygnaty Prezesa Rady Ministrów oraz na wniosek Krajowej Rady Sądownictwa, ukształtowanej w zakresie udziału w niej sędziów w wyniku wyboru przez Sejm Rzeczypospolitej Polskiej piętnastu sędziów, w trybie określonym przepisami ustawy z dnia 8 grudnia 2017 r. o zmianie ustawy o Krajowej Radzie Sądownictwa oraz niektórych innych ustaw (Dz.U. z 2018 r. poz. 3, ze zm.), nie narusza wynikającego z art. 6 ust. 1 Konwencji o ochronie praw człowieka i podstawowych wolności (Dz.U. z 1993 r. nr 61, poz. 284) prawa do rozpoznania sprawy przez niezawisły i bezstronny sąd ustanowiony ustawą, wskutek czego osoba taka nie jest osobą nieuprawnioną do orzekania w rozumieniu art. $439 \S 1$ pkt 1 k.p.k., a skład orzekający sądu, w którym zasiada taka osoba, nie jest sądem nienależycie obsadzonym w rozumieniu art. $439 \S 1$ pkt 2 k.p.k.". Uchwała ta ma także charakter zasady prawa ${ }^{12}$.

${ }^{10}$ Uchwała SN z 8 stycznia 2020 r., sygn. akt I NOZP 3/19, OSNKN 2020/2/10.

${ }^{11}$ Uchwała pełnego składu Izby Dyscyplinarnej SN z 10 kwietnia 2019 r., sygn. akt II DSI 54/18, $<$ http://www.sn.pl/orzecznictwo/SitePages/Najnowsze_orzeczenia.aspx?>, dostęp 5 II 2020.

$12 \mathrm{Na}$ mocy art. $87 \S 1$ ustawy z dnia 8 grudnia 2017 r. o Sądzie Najwyższym (tekst jedn. Dz.U. z 2019 r. poz. 825, ze zm.) uchwały pełnego składu SN, składu połączonych izb oraz składu całej izby, $\mathrm{z}$ chwilą ich podjęcia, uzyskują moc zasad prawnych. 
5. W tej sytuacji 15 stycznia 2020 r. Pierwszy Prezes Sądu Najwyższego, Małgorzata Gersdorf, przedstawiła wniosek o rozstrzygnięcie przez skład SN — Izbę Cywilną, Izbę Karną oraz Izbę Pracy i Ubezpieczeń Społecznych rozbieżności w wykładni prawa występujących w orzecznictwie SN w zakresie dotyczącym następującego zagadnienia prawnego: „Czy udział w składzie sądu powszechnego, sądu wojskowego lub Sądu Najwyższego osoby powołanej do pełnienia urzędu na stanowisku sędziowskim przez Prezydenta Rzeczypospolitej Polskiej na wniosek Krajowej Rady Sądownictwa, ukształtowanej w trybie określonym przepisami ustawy z dnia 8 grudnia 2017 r. o zmianie ustawy o Krajowej Radzie Sądownictwa oraz niektórych innych ustaw (Dz.U. z 2018 r. poz. 3 ze zm.), prowadzi do naruszenia art. 45 ust. 1 Konstytucji Rzeczypospolitej Polskiej, art. 6 ust. 1 Konwencji o ochronie praw człowieka i podstawowych wolności (Dz.U. z 1993 r. nr 61, poz. 284, ze zm.) lub art. 47 Karty praw podstawowych Unii Europejskiej i art. 19 ust. 1 Traktatu o Unii Europejskiej, wskutek czego, zależnie od rodzaju rozpoznawanej sprawy: a) w postępowaniu karnym — osoba taka jest nieuprawniona do orzekania (art. 439 § 1 pkt 1 k.p.k.) albo zachodzi przypadek nienależytej obsady sądu (art. 439 § 1 pkt 2 k.p.k.); b) w postępowaniu cywilnym — skład sądu z udziałem tak powołanej osoby jest sprzeczny z przepisami prawa (art. 379 pkt 4 k.p.c.)?"13.

Warto podkreślić, że Pierwszy Prezes SN zwołała w tym celu posiedzenie tylko trzech z pięciu izb SN, w dodatku bez udziału sędziów tych izb powołanych na wniosek nowej KRS, wskazując, że nie mogą oni, jak i sędziowie Izby Kontroli oraz Izby Dyscyplinarnej, orzekać rzekomo we własnej sprawie. Sytuacja ta budzi dodatkowe wątpliwości prawne ${ }^{14}$.

6. Wobec podważania prerogatywy Prezydenta RP i procedury oraz skutków powoływania sędziów na wniosek KRS, ustalonej w Konstytucji RP i art. 55 i n. ustawy o ustroju sądów powszechnych ${ }^{15}$, poprzez próbę nadania przepisom art. 439 k.p.k. i 379 k.p.c., wskazanym we wniosku Pierwszego Prezesa SN, innego znaczenia niż wynika ono z literalnego brzmienia dotychczasowej wykładni i praktyki stosowania tych

13 Wniosek Pierwszego Prezesa Sądu Najwyższego z 15 stycznia 2020 r. o rozstrzygnięcie przez skład Sądu Najwyższego — Izbę Cywilną, Izbę Karną oraz Izbę Pracy i Ubezpieczeń Społecznych rozbieżności w wykładni prawa występującej w orzecznictwie Sądu Najwyższego, <http://www.sn.pl/aktualnosci/SiteAssets/Lists/Wydarzenia/AllItems/>, dostęp 5 II 2020.

14 Posiedzenie zwołane zostało na podstawie art. $83 \S 1$ ustawy o Sądzie Najwyższym, zgodnie z którym ,jeżeli w orzecznictwie sądów powszechnych, sądów wojskowych lub Sądu Najwyższego ujawnią się rozbieżności w wykładni przepisów prawa będących podstawą ich orzekania, Pierwszy Prezes Sądu Najwyższego lub Prezes Sądu Najwyższego może, w celu zapewnienia jednolitości orzecznictwa, przedstawić wniosek o rozstrzygnięcie zagadnienia prawnego Sądowi Najwyższemu w składzie 7 sędziów lub innym odpowiednim składzie”. To prawda zatem, że „w art. 83 ust. 1 u.SN ustawodawca upoważnił Pierwszego Prezesa Sądu Najwyższego do przedstawienia zagadnienia prawnego takiemu składowi tego Sądu, jaki Prezes uzna za odpowiedni ze względu na wagę i przedmiot zagadnienia". Jednak już przepis kolejny, art. 85 § 1 ustawy, wyraźnie wskazuje, że może to być albo pełny skład Sądu Najwyższego, albo pełny skład Izby, albo też skład połączonych izb. Nie ma mowy o możliwości procedowania bez którychkolwiek z sędziów jednej z połączonych izb z góry wykluczonych z możliwości orzekania.

${ }^{15}$ Ustawa z dnia 27 lipca 2001 r. — Prawo o ustroju sądów powszechnych, tekst jedn. Dz.U. z 2019 r. poz. 52, ze zm. 
przepisów, co w istocie byłoby działalnością prawotwórczą zastrzeżoną dla formy ustawy uchwalanej przez Sejm RP, Marszałek Sejmu RP Elżbieta Witek 20 stycznia 2020 r. skierowała do Trybunału Konstytucyjnego wniosek o rozstrzygnięcie sporu kompetencyjnego między Sejmem RP, Prezydentem RP i Sądem Najwyższym. We wniosku Marszałek zadała następujące pytania:

1) „Czy Sąd Najwyższy jest uprawniony, w tym w drodze uchwały, o której mowa w art. $83 \S 1$ ustawy z dnia 8 grudnia 2017 r. o Sądzie Najwyższym (Dz.U. z 2019 r. poz. 825 ze zm.), podejmowanej w związku z orzeczeniem sądu międzynarodowego, do dokonywania zmian stanu normatywnego w sferze ustroju i organizacji wymiaru sprawiedliwości, czy też, zgodnie z art. 10 ust. 1 i 2, art. 95 ust. 1, art. 176 ust. 2, art. 183 ust. 2 i art. 187 ust. 4 Konstytucji RP, tego rodzaju uprawnienia pozostają w wyłącznej kompetencji ustawodawcy";

2) „Czy kompetencja Prezydenta RP, o której mowa w art. 179 w związku z art. 144 ust. 3 pkt 17 Konstytucji RP, może być rozumiana w ten sposób, że dozwolone jest przyznanie Sądowi Najwyższemu lub innemu sądowi nieprzewidzianych Konstytucją RP kompetencji do oceny skuteczności powołania sędziego, a w szczególności kompetencji do oceny skuteczności nadania sędziemu, którego dotyczy akt powołania, prawa do wykonywania władzy sądowniczej; — czy Sąd Najwyższy może dokonywać wiążącej interpretacji przepisów Konstytucji RP w związku z wykonywaniem przez Prezydenta RP prerogatywy, o której mowa w art. 144 ust. 3 pkt 17 i art. 179 Konstytucji RP, a w szczególności czy Sąd ten może określać, jakie są warunki skuteczności powołania sędziego"’6.

$\mathrm{W}$ dniu 22 stycznia $2020 \mathrm{r}$. TK poinformował o wszczęciu postępowania w sprawie sporu kompetencyjnego z wniosku Marszałka Sejmu (sygn. akt Kpt 1/20). Zastosowanie znalazł zatem przepis art. 86 ust. 1 ustawy z dnia 30 listopada 2016 r. o organizacji i trybie postępowania przed Trybunałem Konstytucyjnym ${ }^{17}$. Zgodnie z tym przepisem „wszczęcie postępowania przed Trybunałem powoduje zawieszenie postępowań przed organami, które prowadzą spór kompetencyjny". Tym samym postępowanie z wniosku Pierwszego Prezesa SN, w ramach którego połączone trzy niepełne izby SN miały rozstrzygnąc rozbieżności w wykładni prawa występujące w orzecznictwie Sądu Najwyższego i które stanowiło asumpt do wniosku Marszałka Sejmu do TK, z mocy prawa uległo zawieszeniu.

\section{Konkluzje}

1. Nie może budzić wątpliwości fakt, że w istniejącym, przedstawionym powyżej stanie faktycznym i prawnym glosowana uchwała SN nie wywołuje żadnych skutków prawnych, ponieważ wydana została w postępowaniu, które uległo z mocy prawa zawieszeniu. Jako taka nie jest zatem również zasadą prawną.

${ }^{16}$ Spór kompetencyjny między Sejmem RP a Sądem Najwyższym oraz między Prezydentem RP a Sądem Najwyższym, <http://trybunal.gov.pl/s/kpt-1-20>, dostęp 5 II 2020.

${ }^{17}$ Dz.U. z 2016 r. poz. 2072, ze zm. 
Istnienie sporu kompetencyjnego między Sejmem, Prezydentem RP i Sądem Najwyższym nie podlega dyskusji. Jedynym organem, który może przesądzić o istnieniu takiego sporu, a w związku z tym także o wszczęciu postępowania w tej sprawie i jej rozstrzygnięciu, jest Trybunał Konstytucyjny. TK dokonał tego 22 stycznia 2020 r., nadając sprawie sygnaturę Kpt 1/20, co automatycznie wywołało skutki prawne $\mathrm{z}$ art. 86 ust. 1 ustawy o TK. W tym stanie rzeczy posiedzenie trzech niepełnych izb SN 23 stycznia 2020 r. należy ocenić jako nieformalne i niemogące doprowadzić do wydania orzeczenia wywołującego skutki prawne.

Powyższe stanowisko potwierdza sędzia SN Wiesław Kozielewicz w zdaniu odrębnym do glosowanej uchwały: „Trybunał Konstytucyjny samodzielnie stwierdza, czy w przedmiotowej sprawie zachodzi spór kompetencyjny (por. uzasadnienie postanowienia TK z 23 czerwca 2008 r., sygn. akt Kpt 1/08, OTK ZU 2008/5A/97). W uzasadnieniu postanowienia z dnia 1 sierpnia 2017 r., sygn. akt II KK 313/16, Sąd Najwyższy trafnie zauważył, że zgodnie z art. 86 ust. 1 ustawy z dnia 30 listopada 2016 r. o organizacji i trybie postępowania przed Trybunałem Konstytucyjnym (powtarzającej w tym zakresie rozwiązania znane wcześniejszym ustawom o Trybunale Konstytucyjnym), wszczęcie przed Trybunałem Konstytucyjnym postępowania w sprawie rozstrzygnięcia sporu kompetencyjnego powoduje zawieszenie postępowań przed organami, które prowadzą spór kompetencyjny. Treść tego przepisu, odczytywanego łącznie z przepisem art. 192 Konstytucji Rzeczypospolitej Polskiej, określającym krąg podmiotów uprawnionych do występowania $\mathrm{z}$ wnioskiem $\mathrm{w}$ sprawach o rozstrzygnięcie sporu kompetencyjnego pomiędzy centralnymi konstytucyjnymi organami państwa oraz z przepisem art. 56 ust. 1 powołanej ustawy, łączącym wszczęcie postępowania przed Trybunałem Konstytucyjnym ze złożeniem przez uprawniony podmiot wniosku, pytania prawnego albo skargi konstytucyjnej, prowadzi do wniosku, że powodem zawieszenia postępowań przed organami, których dotyczy wniosek podmiotu zwracającego się do Trybunału Konstytucyjnego o rozstrzygnięcie sporu kompetencyjnego, nie jest istnienie rzeczywistego sporu o kompetencje, lecz wyłącznie formalne wszczęcie postępowania w tym przedmiocie. Przyjęte przez ustawodawcę rozwiązanie sprawia, że od chwili wpływu wniosku o rozstrzygnięcie sporu kompetencyjnego, to Trybunał Konstytucyjny staje się wyłącznie właściwy do orzekania o tym, czy zachodzą warunki do rozstrzygania sporu, o którym mowa w art. 85 ustawy z dnia 30 listopada 2016 r. o organizacji i trybie postępowania przed Trybunałem Konstytucyjnym"18.

Nie ma też wątpliwości, że zarówno treść pytań Pierwszego Prezesa SN, zawartych we wniosku z 15 stycznia 2020 r. o rozstrzygnięcie rozbieżności w wykładni prawa występujących w orzecznictwie SN, jak i treść glosowanej uchwały jednoznacznie przesądzają, że SN swym orzeczeniem zamierzał od początku wkroczyć w materię zarezerwowaną dla władzy ustawodawczej. Ujęte to zostało precyzyjnie w stanowisku Sejmu z 28 stycznia 2019 r., zawartym w aktach sprawy Kpt 1/20. Marszałek E. Witek w imieniu Sejmu RP stwierdziła, że choć uchwała SN z 23 stycznia 2020 r.

${ }^{18}$ Uzasadnienie zdania odrębnego sędziego SN W. Kozielewicza złożonego do uchwały składu połączonych Izb: Cywilnej, Karnej, Pracy i Ubezpieczeń Społecznych SN z 23 stycznia 2020 r., BSA 1-4110-1/20. 
formalnie nie jest źródłem prawa $\mathrm{w}$ znaczeniu konstytucyjnym ${ }^{19}$, to swą treścią próbuje istotnie modyfikować obowiązujący w RP porządek normatywny. Owe „nowości normatywne sprowadzają się nie tylko do zanegowania - wbrew stanowisku Trybunału Konstytucyjnego - zgodności z ustawą zasadniczą trybu powołania Krajowej Rady Sądownictwa, lecz do stworzenia mechanizmu weryfikacji skutków prezydenckiego aktu powołania sędziego. Podejmując tę uchwałę, Sąd Najwyższy wkroczył więc w uprawnienia ustawodawcy i ustrojodawcy"20.

W kontekście powyższego w żaden sposób nie można zgodzić się ze stwierdzeniami zawartymi w piśmie Pierwszego Prezesa SN z 23 stycznia br., jak i w stanowisku Sądu Najwyższego z dnia 27 stycznia br. ${ }^{21}$, w którym Pierwszy Prezes SN utrzymuje, jakoby nie istniał żaden spór kompetencyjny, a wniosek Marszałka Sejmu w tej sprawie stanowi nadużycie jego kompetencji. Biorąc pod uwagę całokształt dokumentów i orzeczeń w przedmiotowej sprawie, w szczególności zaś treść glosowanej uchwały, stanowisko to nie znajduje żadnego potwierdzenia ani uzasadnienia.

2. W nawiązaniu do powyższego należy stwierdzić, że SN nie ma żadnych podstaw prawnych do kategoryzowania sędziów w stanie czynnym i do odbierania im prawa zasiadania w składach orzekających wydających skuteczne prawnie orzeczenia sądowe. Zgodnie z obowiązującym prawem powoływanie sędziów to prerogatywa Prezydenta RP (art. 144 ust. 3 pkt 17 Konstytucji RP). Takie ujęcie kompetencji w zakresie powoływania sędziów sprawia, że z jednej strony Prezydent RP nie ma prawnego obowiązku uwzględnienia wniosku KRS, choć też odmowa wykonania tego wniosku powinna się zdarzyć tylko w sytuacji nadzwyczajnej i powinna być poprzedzona przedstawieniem KRS zastrzeżeń przez zasiadającego $\mathrm{w}$ niej przedstawiciela prezydenta ${ }^{22}$. $\mathrm{Z}$ drugiej zaś strony konsekwencją takiego stanu rzeczy jest niedopuszczalność zaskarżenia tego aktu w jakimkolwiek trybie, $w$ tym na drodze sądowej ${ }^{23}$.

Należy także podkreślić, że „[...] z chwilą powołania przez Prezydenta powstaje stosunek służbowy sędziego. Brak przy tym jakichkolwiek dalszych regulacji konstytucyjnych, pozwalających na dokonywanie ocen skuteczności aktu powołania sędziego. Powoduje to w konsekwencji, że nie jest dopuszczalne ani negowanie, ani nawet poddawanie badaniu istnienia stosunku służbowego sędziego ukształtowanego aktem

19 Są nimi wyłącznie: Konstytucja RP, ratyfikowane umowy międzynarodowe, prawo stanowione przez organy UE, ustawy, rozporządzenia z mocą ustawy, rozporządzenia wykonawcze i akty prawa miejscowego; confer art. 87, art. 91 ust. 3 i art. 234 Konstytucji RP.

${ }^{20}$ Uzasadnienie stanowiska Sejmu RP z 28 stycznia 2020 r. skierowanego do TK w sprawie o sygn. akt Kpt 1/20.

${ }^{21}$ Stanowisko SN w sprawie zainicjowanej wnioskiem Marszałka Sejmu o rozstrzygnięcie sporów kompetencyjnych między Sądem Najwyższym a Sejmem oraz między Prezydentem RP a Sądem Najwyższym z 27 stycznia 2019 r. skierowane do TK w sprawie o sygn. akt Kpt 1/20.

22 Vide m.in. W. Sokolewicz, Konstytucyjna regulacja władzy sądowniczej, [w:] Konstytucja, ustrój, system finansowy państwa. Księga pamiątkowa ku czci prof. Natalii Gajl, Warszawa 1999, s. 174; J. Ciapała, Charakter kompetencji Prezydenta RP. Uwagi w kontekście kompetencji w zakresie powotywania sędziów, „Przegląd Sejmowy” 2008, nr 4(87), s. 31.

${ }^{23}$ Confer wyrok TSUE z 19 listopada 2019 r. .., pkt 145. 
prezydenckim. To bowiem wyłącznie Prezydent RP ponosi odpowiedzialność za zrealizowanie swej prerogatywy i nie istnieje możliwość — niezależnie od ewentualnych uchybień poprzedzających skorzystanie z niej, zaistniałych na etapie regulowanego ustawami postępowania poprzedzającego powołanie do pełnienia urzędu na stanowisku sędziego — skutecznego podważenia tego aktu [...], uznania in abstracto, że dana osoba powołana do pełnienia urzędu na stanowisku sędziego, nie posiada statusu uprawniającego jej do wykonywania zadań z zakresu wymiaru sprawiedliwości”24. Dzieje się tak dlatego, że nominacja sędziowska nie jest aktem abstrakcyjnym i już w samym akcie powołania określa się stanowisko sędziowskie, jakie będzie zajmowała indywidualnie oznaczona osoba ${ }^{25}$.

Powyższe konstatacje potwierdza ze szczególną emocją sędziego SN Zbigniew Myszka w votum separatum do glosowanej uchwały: „Zdanie odrębne składam w poszanowaniu Konstytucji Rzeczypospolitej Polskiej oraz w obronie nowo powołanych sędziów, którzy uzyskali nominacje sędziowskie od Prezydenta Rzeczypospolitej Polskiej i na ogół nie zważają na własne potrzeby osobiste czy rodzinne, ale w poczuciu konstytucyjnego obowiązku (art. 178 ust. 1 Konstytucji RP) realizują w imieniu Rzeczypospolitej Polskiej odpowiedzialną misję niezależnego, bezstronnego i niezawisłego orzekania w rozmiarze często przekraczającym zwykłe możliwości. Za taką służbę należy się szacunek, a nie poniżające i upokarzające uchwałodawcze piętno lub status podejrzanych sędziów, którzy nie powinni dalej orzekać lub mają być stygmatyzowani ograniczeniami wykonywania jurysdykcji, choćby pro futuro od daty podjęcia kontestowanej uchwały"26.

3. Powyższe potwierdza postanowienie NSA z 27 stycznia 2020 r. (sygn. akt I OSK 1917/18), w którym sąd oddalił wniosek o wyłączenie sędziego. W zawisłej przed sądem sprawie o udostępnienie informacji publicznej dopuszczono do udziału w charakterze uczestnika na prawach strony Fundację, która następnie zgłosiła wniosek o wyłączenie sędziego NSA Mirosława Wincenciaka od udziału w sprawie. We wniosku o wyłączenie wskazano, że sędzia ten został powołany na wniosek KRS powołanej na podstawie ustawy z 8 grudnia 2017 r. Naczelny Sąd Administracyjny oddalił wniosek Fundacji i stwierdził w uzasadnieniu swego postanowienia w szczególności, że „,...] w sytuacji, gdy Prezydent nie znalazł podstaw do odmowy powołania na stanowisko sędziego, to Naczelny Sąd Administracyjny w postępowaniu o wyłączenie sędziego nie może dokonywać oceny prawidłowości powołania tego sędziego. Instytucja wyłączenia sędziego nie służy kontroli działań Prezydenta podejmowanych w ramach

${ }^{24}$ Druk nr 69, Sejm IX kadencji, uzasadnienie do projektu ustawy o zmianie ustawy — Prawo o ustroju sądów powszechnych, ustawy o Sądzie Najwyższym oraz niektórych innych ustaw, s. 35-36.

${ }_{25}$ Vide P. Czarny, Realizacja konstytucyjnych kompetencji Prezydenta RP w odniesieniu do sadów i Krajowej Rady Sadownictwa, [w:] System rzadów Rzeczpospolitej Polskiej. Założenia konstytucyjne a praktyka ustrojowa, red. M. Grzybowski, Warszawa 2006; confer art. $55 \S 2$ ustawy — Prawo o ustroju sądów powszechnych.

${ }^{26}$ Zdanie odrębne sędziego SN Zbigniewa Myszki do uchwały składu połączonych Izb: Cywilnej, Karnej oraz Pracy i Ubezpieczeń Społecznych Sądu Najwyższego z 23 stycznia 2010 r., BSA I-4110-1/20, która wywołuje ekstraordynaryjne kontrowersje konstytucyjne, ustrojowe, kompetencyjne i cywilizacyjne. 
jego konstytucyjnych kompetencji określonych w art. 179 i art. 144 ust. 2 i ust. 3 pkt 17 Konstytucji”27.

Tym samym orzeczenie to w sposób jaskrawy jest przeciwne do glosowanej uchwały SN. Precyzyjnie wskazuje na to m.in. Marek Dobrowolski. Jego zdaniem „NSA odwołuje się do ujęcia tradycyjnego, konstytucyjnie uzasadnionego oraz utrwalonego w judykaturze i w dotychczasowej doktrynie prawa, zgodnie z którym ową stabilność zapewnia powołanie sędziów w drodze prerogatywy prezydenckiej (jeśli prezydent nie znalazł podstaw do odmowy powołania na stanowisko sędziego, to nie można dokonywać oceny prawidłowości powołania takiego sędziego). Sąd Najwyższy natomiast, nie podważając (formalnie rzecz biorąc) prezydenckiego powołania, zauważa nieprawidłowości i nadaje im znaczącą rangę ustrojową, a następnie dąży do wytworzenia drogi sądowej umożliwiającej kontrolę tychże powołań (zgodnie z tezą: jeśli są wątpliwości, to dla pewności orzecznictwa należy w drodze rozstrzygnięcia sądowego je rozwiać)"228.

Nie ma przy tym wątpliwości, że to NSA działa na podstawie obowiązujących przepisów prawa i w granicach przez nie określonych, a zatem w zgodzie $\mathrm{z}$ wymogami praworządności. Jak bowiem trafnie ujmuje to M. Dobrowolski, ,[...] spór sprowadza się do tego, który organ państwa (prezydent czy Sąd Najwyższy i sądy odwoławcze) będzie miał ostatnie słowo przy dopuszczaniu do sprawowania władzy sądzenia (oceny statusu sędziów albo kwalifikacji kandydatów na sędziów). Należy przy tym podkreślić, że zarówno Konstytucja RP, jak i wyrok TSUE nie pozostawiają w tym względzie wątpliwości - sędziowski status osób powoływanych przez prezydenta wykonującego swoją prerogatywę nie może być podważany"29.

4. Należy także uznać za błędne powoływanie orzeczenia TSUE z 19 listopada 2019 r. jako podstawy prawnej zarówno orzeczenia SN z 5 grudnia 2019 r., jak i glosowanej uchwały. Pomijając fakt bezsporny, że wyroki TSUE nie mają charakteru i mocy źródła prawa powszechnie obowiązującego i nie są prawotwórcze, o czym kilka refleksji jeszcze w dalszej części glosy, to precyzyjnie wadę takiego upatrywania w listopadowym rozstrzygnięciu unijnego Trybunału podkreślił NSA, który wyrok ten interpretował ściśle. Wskazywał, że wyrok TSUE został wydany „w ramach sprawy wymagającej oceny zgodności z prawem UE przepisów dotyczących Izby Dyscyplinarnej” i „dopiero łączna ocena wątpliwości związanych z powołaniem KRS i Izby Dyscyplinarnej” pozwala sądowi krajowemu na dokonanie oceny niezależności tej izby. Dodał również jednoznacznie, że ,[...] z wyroku TSUE nie wynika [...] możliwość automatycznego zakwestionowania każdej nominacji na urząd sędziego lub asesora do innego sądu niż Izba Dyscyplinarna”. A zatem, jak wyjaśnia to M. Dobrowolski, „test niezawisłości

${ }^{27}$ Postanowienie NSA z 27 stycznia 2020 r. o odmowie wyłączenia sędziego powołanego na wniosek KRS w obecnym składzie, <http://nsa.gov.pl/komunikaty/postanowienie-nsa-o-odmowie-wylaczenia-sedziego-powolanego-na-wniosek-krs>, dostęp 5 II 2020.

${ }_{28}^{2}$ M. Dobrowolski, SN i NSA - odmienne oceny statusu sędziego powołanego z udziałem obecnej KRS, „Dziennik. Gazeta Prawna”, 4 II 2020.

${ }^{29}$ Ibidem. 
ukształtowany w wyroku TSUE stanowi integralną całość i służy do oceny wyłącznie Izby Dyscyplinarnej. Wykonanie więc wyroku TSUE sprowadza się do realizacji tego celu" ${ }^{\prime 3}$.

Tymczasem w glosowanej uchwale SN, powołując się na ten sam wyrok TSUE, zakwestionował możliwość orzekania i nawet wadliwość orzecznictwa (w przypadku sędziów Izby Kontroli Nadzwyczajnej i Spraw Publicznych SN) nie tylko sędziów Izby Dyscyplinarnej, ale wszystkich sędziów sądów powszechnych, wojskowych i Sądu Najwyższego, wychodząc tym samym radykalnie poza delegację zawartą w wyroku TSUE - zresztą delegację nie swoją, ale przeznaczoną wyłącznie dla Izby Pracy i Ubezpieczeń Społecznych SN w konkretnej sprawie, w której sąd odesłał pytania prejudycjalne do TSUE. Nie jest to - bo w prawie krajowym, jak i unijnym nie może być - delegacja uniwersalna i podstawa prawna orzecznictwa wszystkich możliwych sądów, w tym połączonych izb SN, co już wykazano w niniejszym opracowaniu.

W tym kontekście w żaden sposób nie można zgodzić się ze stanowiskiem zawartym w uzasadnieniu glosowanego orzeczenia, że ,podejmując uchwałę w składzie połączonych Izb Cywilnej, Karnej oraz Pracy i Ubezpieczeń Społecznych, Sąd Najwyższy wykonuje wyrok Trybunału Sprawiedliwości UE z dnia 19 listopada 2019 r.”. SN nie wykonał bowiem wyroku TSUE, tylko korzystając z niektórych elementów tego wyroku, uzurpował sobie prawo stworzenia drogi prawnej do oceny wszystkich sędziów sądów powszechnych i wojskowych oraz Sądu Najwyższego powołanych z udziałem obecnej KRS.

W uzasadnieniu swego wyroku z 5 grudnia 2019 r. Izba Pracy i Ubezpieczeń Społecznych SN wskazała dodatkowo, że podstawą do wydania orzeczenia, ale także do stwierdzenia, że Izba Dyscyplinarna SN nie jest sądem w rozumieniu prawa europejskiego, są pkt 158 i 160-166 listopadowego orzeczenia TSUE. Unijny sąd stwierdził w nich, że ,[...] zgodnie z zasadą pierwszeństwa (prawa wspólnotowego przed krajowym) w razie niemożności dokonania wykładni uregulowania krajowego w sposób zgodny z wymogami określonymi w prawie Unii sąd krajowy, do którego należy w ramach jego kompetencji stosowanie przepisów prawa Unii, jest zobowiązany zapewnić pełną ich skuteczność, w razie potrzeby nie stosując, z własnej inicjatywy, wszelkich sprzecznych z nimi przepisów prawa krajowego, także późniejszych, bez konieczności żądania uprzedniego uchylenia tych przepisów w drodze ustawodawczej lub w jakimkolwiek innym trybie konstytucyjnym ani bez konieczności oczekiwania na takie uchylenie (wyrok z 24 czerwca 2019 r., Popławski, C-573/17, EU:C:2019:530, pkt 58 i przytoczone tam orzecznictwo)”. Dlatego „każdy sąd krajowy orzekający w ramach swoich kompetencji ma, ściślej rzecz ujmując, jako organ państwa członkowskiego obowiązek odstąpić od stosowania wszelkiego przepisu prawa krajowego sprzecznego z bezpośrednio skutecznym przepisem prawa Unii w ramach toczącego się przed tym sądem sporu (wyrok z 24 czerwca 2019 r., Popławski, C-573/17, EU:C:2019:530, pkt 61 i przytoczone tam orzecznictwo)". Z tego wynika, jak skonstatował dalej TSUE,

30 Ibidem. 
iż „gdy okazuje się, że przepis krajowy zastrzega właściwość do rozpoznania sporu takiego jak ten w postępowaniu głównym na rzecz organu, który nie spełnia wymogów niezawisłości lub bezstronności ustanowionych w prawie Unii, w szczególności w art. 47 karty praw podstawowych, inny organ, przed który wniesiono taki spór, ma obowiązek, w celu zagwarantowania skutecznej ochrony sądowej w rozumieniu tego art. 47 i w myśl zasady lojalnej współpracy zapisanej w art. 4 ust. 3 TUE, odstąpić od stosowania tego przepisu krajowego, ażeby spór ten mógł zostać rozpatrzony przez sąd, który spełnia powyższe wymogi i który byłby właściwy w danej dziedzinie, gdyby wspomniany przepis nie stał temu na przeszkodzie, czyli co do zasady sąd, który był do tego właściwy zgodnie z przepisami obowiązującymi przed wprowadzeniem zmiany ustawodawczej przyznającej tę właściwość organowi niespełniającemu wyżej wymienionych wymogów (vide analogicznie wyroki z: 22 maja 2003 r., Connect Austria, C-462/99, EU:C:2003:297, pkt 42; 2 czerwca 2005 r., Koppensteiner, C-15/04, EU:C:2005:345, pkt 32-39)"31.

Powyższe wskazania unijnego Trybunału jednoznacznie dowodzą, że TSUE nie stwierdził nielegalności i braku możliwości funkcjonowania ani Izby Dyscyplinarnej, ani KRS. Nie dał też żadnej podstawy do takiego samosądu żadnemu sądowi, w tym Sądowi Najwyższemu. TSUE przywołuje jedynie orzecznictwo na poparcie zasady pierwszeństwa prawa wspólnotowego przed prawem krajowym w celu przekazania - w cytowanej już w tym opracowaniu sentencji orzeczenia - uprawnienia Izbie Pracy i Ubezpieczeń Społecznych do zbadania, czy Izba Dyscyplinarna SN ma gwarancje niezależności i w związku z tym możliwości odstąpienia od zastosowania przepisów ustawy o Sądzie Najwyższym i samodzielnego rozpatrzenia sprawy z odwołania sędziego NSA od postanowienia KRS. Tyle i tylko tyle. Co więcej, TSUE nie stwierdził nawet samodzielnie, że Izba Dyscyplinarna takich gwarancji nie ma.

Dlatego wszelkie inne wnioski o rzekomej podstawie prawnej do samodzielnego badania konstytucyjności prawa przez sądy w trybie tzw. kontroli rozproszonej, do stwierdzania o charakterze prawotwórczym, że Izba Dyscyplinarna nie jest sądem w rozumieniu prawa Unii Europejskiej i w rozumieniu prawa krajowego, czy też do możliwości podważania legalności powołania sędziów przez Prezydenta RP, nie znajdują uzasadnienia $\mathrm{w}$ orzeczeniu TSUE oraz obowiązujących przepisach prawa zarówno polskiego, jak i europejskiego i są przejawem anarchizacji polskiego wymiaru sprawiedliwości.

5. Problemem prawnym budzącym wątpliwości i odmienne interpretacje pozostaje kwestia nadrzędności Konstytucji RP nad prawem unijnym, a zatem zakres oddziaływania zasady pierwszeństwa prawa wspólnotowego przed krajowym, sformułowanej w orzecznictwie TSUE (wcześniej Europejskiego Trybunału Sprawiedliwości). Zasada ta została zawarta już w wyroku z 15 lipca 1964 r. w sprawie Flaminio Costa vs. ENEL ${ }^{32}$.

${ }^{31}$ Wyrok TSUE z 19 listopada 2019 r. ..., pkt 158, 160-165.

${ }^{32}$ Wyrok TSUE z 15 lipca 1964 r. w sprawie Flaminio Costa vs. ENEL, sygn. C-6/64, <https://curia. europa.eu/arrets>, dostęp 5 II 2020. 
Nigdy jednak nie została zapisana wprost $w$ traktatach unijnych. Nie ma przy tym wątpliwości, że odnosi się ona tylko do tych spraw z zakresu działania Unii Europejskiej, które zostały wyraźnie UE oddane w ramach przekazania kompetencji na mocy traktatów akcesyjnych.

Faktem jest, jak słusznie podkreśla się $\mathrm{w}$ doktrynie, że w związku z członkostwem RP w Unii Europejskiej nadrzędna pozycja Konstytucji RP, wyrażona w art. 8 ust. 1, ulega pewnej modyfikacji. Pogląd ten „opiera się na uznaniu kompleksowego charakteru aktu integracji i specjalnym trybie jego ratyfikacji w referendum. Można więc by tu mówić o konstytucyjnym akcie integracji dokonanym za zgodą samej Konstytucji i autonomicznym wobec jej pozostałych postanowień" ${ }^{33}$. Jednak zawsze należy mieć na względzie normę z art. 90 ust. 1 Konstytucji RP, zgodnie z którą „Rzeczpospolita Polska może na podstawie umowy międzynarodowej przekazać organizacji międzynarodowej lub organowi międzynarodowemu kompetencje organów państwowych w niektórych sprawach". Wynika z tego, że nie we wszystkich sprawach, a kompetencje te i sprawy muszą być wyraźnie określone w umowie międzynarodowej ${ }^{34}$. Dlatego też rację miał Bogusław Banaszak, stwierdzając, że ,[...] państwa członkowskie zachowują prawo do oceny, czy prawodawcze organy wspólnotowe (unijne), wydając określony akt (przepis prawa), działały w ramach kompetencji przekazanych i czy wykonywały swe uprawnienia zgodnie z zasadami subsydiarności i proporcjonalności. Przekroczenie tych ram powoduje, że wydane poza nimi akty (przepisy) nie są objęte zasadą pierwszeństwa prawa wspólnotowego" 35 .

W kontekście glosowanej uchwały należy przytoczyć słuszną opinię Mariusza Muszyńskiego. Jego zdaniem, zgodnie z treścią nadaną tej zasadzie przez TSUE (ETS), „zasada ta nie wyłącza obowiązywania prawa krajowego sprzecznego z normą unijną"36. Żaden organ UE nie ma bowiem prawa do orzekania ze skutkiem automatycznej utraty mocy obowiązującej przepisów prawa krajowego. Takim organem jest wyłącznie sąd konstytucyjny wewnątrz państw członkowskich — w przypadku Polski jest nim Trybunał Konstytucyjny. Sprzeczność prawa krajowego z prawem unijnym blokuje jedynie jego zastosowanie w konkretnej sprawie i to tylko w sytuacji objętej reżimem prawa unijnego. Pogląd ten koresponduje ze stanowiskiem innych przedstawicieli doktryny, zgodnie z którym ,sprzeczny z prawem wspólnotowym przepis nie traci mocy

${ }^{33}$ B. Banaszak, Konstytucja Rzeczypospolitej Polskiej. Komentarz, Warszawa 2012, s. 85.

${ }^{34}$ Confer Konstytucja RP, t. I: Komentarz do art. 1-86, red. M. Safjan, L. Bosek Warszawa 2016, s. 318: „Konstytucja dopuszcza w art. 90 przekazanie kompetencji organów władzy państwowej jedynie w niektórych sprawach, co w świetle polskiego orzecznictwa konstytucyjnego oznacza zakaz przekazania ogółu kompetencji danego organu, przekazania kompetencji w całości spraw w danej dziedzinie i zakaz przekazania kompetencji co do istoty spraw określających gestie danego organu władzy państwowej [...]". Kompetencją i sprawą nie do przekazania jest natomiast, ze względu na konstytucyjną zasadę suwerenności Narodu, ,wyłączna kompetencja jurysdykcyjna odnośnie do własnego terytorium i obywateli” (ibidem, s. 317).

${ }_{35}$ Ibidem, s. 87; confer wyrok TK z 11 maja 2005 r., sygn. akt K 18/04, OTK 2005/5A/49.

${ }^{36}$ M. Muszyński, Granice kompetencyjne Trybunatu Konstytucyjnego wobec prawa Unii Europejskiej, [w:] Tempora mutantur cum legibus. Księga jubileuszowa z okazji 20-lecia Wydziatu Prawa i Administracji Uniwersytetu Kardynała Stefana Wyszyńskiego w Warszawie, red. A. Tarwacka, Warszawa 2019, s. 121. 
obowiązującej, lecz może wywierać skutki prawne w sytuacjach niemających związku ze Wspólnotą" ${ }^{37}$.

Biorąc pod uwagę powyższe, dodać należy, że także TSUE nie ma prawa uchylania obowiązywania przepisów prawa krajowego. Jego orzeczenia nie mają bowiem charakteru prawotwórczego oraz mocy prawnej bezwzględnie i powszechnie obowiązującej i nie można ich uznać za precedensowe w ujęciu formalnym, co jest charakterystyką orzeczeń w systemie anglosaskim common law, a nie w naszym kontynentalnym civil law. Orzeczenia te mają co najwyżej tzw. względną, warunkową moc obowiązującą erga omnes, co nie czyni z nich podstawy prawnej do orzekania w każdej sprawie, a jedynie powoduje, że wyroki TSUE powoływane są w kontekście wykładni i interpretacji prawa unijnego. Jak bowiem słusznie podkreśla się w literaturze przedmiotu, ,[...] traktaty założycielskie nie przyznają orzeczeniom TSUE mocy powszechnie wiążącej (nie zaliczają orzecznictwa TSUE do źródeł unijnego prawa). Tym samym, można by na tej podstawie twierdzić, że Państwa Członkowskie nie wyraziły zgody na taką moc tych orzeczeń, w konsekwencji czego - poza sprawą, jakiej dotyczy dany wyrok - ich sądy (inne organy stosujące prawo) nie muszą się do treści tych orzeczeń bezwzględnie lub nawet wcale stosować. Po drugie, w przypadku dokonywania przez TSUE wykładni rozszerzającej oraz wywodzenia norm bardziej szczegółowych z ogólnych postanowień prawa unijnego, trybunał ten, przy nadaniu jego orzecznictwu mocy powszechnie wiążącej, prawo by nie tylko stosował, ale i bez wątpienia tworzył. Co więcej, tak stanowione prawo byłoby prawem stojącym (mającym pierwszeństwo) nad prawodawstwem krajowym, niepodlegającym jednocześnie żadnej formie demokratycznej i «narodowej» kontroli. Oprócz niego samego, nie byłoby bowiem nikogo, kto byłby władny autorytatywnie stwierdzić, czy na skutek prawotwórczej działalności TSUE nie doszło już nie tylko do przekroczenia zakresu jego własnych kompetencji, lecz i kompetencji, jakie Państwa Członkowskie zgodziły się w związku z akcesją scedować na Unię Europejską. W tym też sensie, w mocy powszechnie wiążącej orzeczeń pochodzących od TSUE można by próbować upatrywać swoiste zagrożenie dla suwerenności, a ściślej mówiąc tego, co z niej jeszcze zostało, państw będących członkami Unii Europejskiej" ${ }^{38}$. Dlatego też orzeczenia TSUE mają charakter co najwyżej swoistej lex imperfecta ${ }^{39}$.

6. Syntetyczna konkluzja niniejszego opracowania w kontekście wszystkich wcześniej przytoczonych i sformułowanych argumentów może być tylko jedna — Sąd Najwyższy nie miał prawa podjęcia glosowanej uchwały z 23 stycznia 2020 r. i to zarówno na podstawie prawa formalnego, jak i materialnego. $\mathrm{Z}$ jednej bowiem strony uchwała

${ }^{37}$ B. Banaszak, op. cit., s. 86; vide J.W. Tkaczyński, R. Potorski, R. Willa, Unia Europejska. Wybrane aspekty ustrojowe, Toruń 2007, s. 28.

${ }_{38}$ M. Koszowski, Granice zwiazania orzecznictwem Trybunatu Sprawiedliwości Unii Europejskiej, [w:] Granice państwa jako granice jurysdykcji w Unii Europejskiej, red. S.M. Grochalski, Dąbrowa Górnicza 2012, s. 36.

${ }^{39}$ Ibidem, s. 53. 
podjęta została w ramach postępowania, które dzień wcześniej, z uwagi na wszczęcie postępowania w sprawie sporu kompetencyjnego między Sejmem RP, Prezydentem RP i Sądem Najwyższym, zostało z mocy prawa (art. 86 ust. 1 ustawy o organizacji i trybie postępowania przed TK) zawieszone. Z drugiej strony brakuje jakichkolwiek podstaw w prawie materialnym do orzekania przez SN o legalności lub nawet tylko braku możliwości niewadliwego orzekania $\mathrm{z}$ tego powodu przez sędziów powołanych przez Prezydenta RP. W szczególności podstawą taką nie jest (bowiem i w żadnym innym wypadku nie mogłoby być) orzeczenie Trybunału Sprawiedliwości Unii Europejskiej z 19 listopada $2019 \mathrm{r}$.

$\mathrm{Z}$ tego powodu glosowana uchwała od samego momentu jej podjęcia nie wywołuje żadnych skutków prawnych. Upatrywanie zaś w art. 439 § 1 pkt 2 k.p.k. i 379 pkt 4 k.p.c. podstaw do stwierdzenia, że sędziowie SN powołani przez Prezydenta RP na wniosek KRS powołanej na podstawie ustawy z 8 grudnia 2017 r. nie mają prawa do niewadliwego orzekania, a ich zasiadanie w składzie orzekającym stanowi nienależytą obsadę sądu albo sprzeczność składu sądu z przepisami prawa, jest w istocie działalnością prawotwórczą, nie mieszczącą się w granicach kompetencji Sądu Najwyższego, a jednocześnie podważającą konstytucyjną prerogatywę Prezydenta RP.

Na marginesie można jeszcze podnieść jedną wątpliwość prawną. Otóż zgodnie z art. $88 \S 2$ i 3 ustawy o Sądzie Najwyższym odstąpienie od zasady prawnej uchwalonej przez izbę wymaga ponownego rozstrzygnięcia w drodze uchwały odpowiednio przez właściwą izbę, połączone izby lub pełny skład SN, a w przypadku gdy skład jednej izby SN zamierza odstąpić od zasady prawnej uchwalonej przez inną izbę, rozstrzygnięcie następuje $\mathrm{w}$ drodze uchwały obu tych izb lub też izby te mogą przedstawić zagadnienie prawne do rozpoznania przez pełny skład SN. W tym kontekście nie powinno budzić wątpliwości, że zasad prawnych uchwalonych 10 kwietnia $2019 \mathrm{r}$. przez Izbę Dyscyplinarną Sądu Najwyższego, jak i 8 stycznia 2020 r. przez Izbę Kontroli Nadzwyczajnej i Spraw Publicznych SN nie da się zmienić bez udziału tych izb. Skoro tak, to w związku z wykluczeniem sędziów obu tych izb z orzekania w dniu 23 stycznia 2020 r. przez Pierwszego Prezesa SN, zasady prawne przez nie ustalone pozostają w mocy.

7. Ostatecznie z uwagi na chaos i wątpliwości niektórych sędziów i prezesów sądów TK wydał 28 stycznia 2020 r. postanowienie zabezpieczające (sygn. akt Kpt 1/20). Wykorzystując normę art. 86 ust. 2 ustawy o organizacji i trybie postępowania przed TK, tymczasowo uregulował kwestie sporne i do czasu rozstrzygnięcia sporu kompetencyjnego wstrzymał wykonywanie przez SN kompetencji do wydawania uchwał, jeżeli miałyby dotyczyć zgodności z prawem krajowym, międzynarodowym oraz orzecznictwem sądów międzynarodowych: 1) ukształtowania składu KRS, 2) trybu przedstawiania Prezydentowi RP kandydatur do pełnienia urzędu na stanowisku sędziego, 3) wykonywania prerogatywy Prezydenta RP do powoływania sędziów, 4) kompetencji do pełnienia urzędu na stanowisku sędziego przez osobę powołaną przez Prezydenta RP na wniosek Krajowej Rady Sądownictwa. TK wstrzymał także stosowanie, od dnia jej 
wydania, uchwały składu połączonych Izb Cywilnej, Karnej oraz Pracy i Ubezpieczeń Społecznych Sądu Najwyższego z 23 stycznia 2020 r. i stwierdził jednoznacznie, że:

1) niedopuszczalne jest stosowanie art. $439 \S 1$ pkt 2 ustawy z dnia 6 czerwca 1997 r. - Kodeks postępowania karnego oraz art. 379 pkt 4 ustawy z dnia 17 listopada 1964 r. - Kodeks postępowania cywilnego w rozumieniu przyjętym w przedmiotowej uchwale,

2) kompetencja do orzekania przez sędziego powołanego na urząd przez Prezydenta RP na wniosek KRS nie może być ograniczana,

3) orzeczenia wydane przez składy orzekające, w których zasiadali sędziowie wskazani w pkt 2, mają moc obowiązującą.

Tym samym wszelkie tlące się jeszcze wątpliwości co do tego, czy glosowana uchwała SN wywołuje jakiekolwiek skutki prawne, zostały ostatecznie rozwiane.

\section{Przemysław Czarnek*}

* Dr hab. Przemysław Czarnek, Katolicki Uniwersytet Lubelski Jana Pawła II, Wydział Prawa, Prawa Kanonicznego i Administracji, Katedra Prawa Konstytucyjnego, pczarnek@kul.lublin.pl,https://orcid.org/0000-0002-3904-5965 